\title{
Types of weather at selected meteorological stations in Sri Lanka
}

\begin{tabular}{|l|l}
\hline Ksenia Dobrowolska & $\begin{array}{l}\text { Department of Climatology, Faculty of Earth Science, } \\
\text { University of Silesia, Będzińska 60, 41-200 Sosnowiec, Poland } \\
\text { kseniadobrowolska@ gmail.com }\end{array}$
\end{tabular}

\begin{abstract}
The paper aims to present the structure of weather types at two meteorological stations Galle and Nuwara Eliya (Sri Lanka). The weather type is determined as a generalized characteristic of the weather by features and gradation of selected meteorological elements. All available data on daily average, maximum and minimum air temperature, the average daily total cloud amount and the daily precipitation amount come from OGIMET database and have been used to designate weather types. The analysis was performed for the period April 2002 March 2012. The weather types were designated based on the modified A. Woś (2010) classification of weather types. The frequency of groups, subgroups, classes, and types of weather were determined. Additionally, determined frequency of sequences of days with the same weather type.

The analysis allows to conclude, that the structure of weather types at both stations was poorly differentiated. There were very stable weather conditions. In Galle, the most frequent was very warm, partly cloudy weather, without precipitation (920) and in Nuwara Eliya warm, partly cloudy weather without precipitation (820).
\end{abstract}

Key words: types of weather, complex climatology, Galle, Nuwara Eliya, Sri Lanka (Ceylon)

DOI: $10.2478 / \mathrm{ctg}-2014-0017$

Received: $9^{\text {th }}$ September, 2014

Accepted: $29^{\text {th }}$ November, 2014

\section{Introduction}

Complex climatology determines the climate as "the multiannual weather regime, understood as the entirety of weather conditions, as well as their characteristic sequence" (Ferdynus and Marsz 2000). In contrast to classical climatology, climate is not described by the average value of each individual meteorological element, but as their interdependence, simultaneous, comprehensive impact in a given geographical environment. This approach allows to fully determine the state of the weather (type of weather) in given area (Piotrowicz 2010). Weather type is determined as a generalized characteristic of the weather by features and gradation of selected meteorological elements (Woś 1996).

Application of a complex climatology methods have been extensively described in literature (Czubukow 1949; Woś 1996, 2010; Ferdynus 1997, 2004, 2013; Howe 1925; Kossowski 1968; Maheras 1984; Marsz 1992; Nichols 1925; Michailidou et al. 2009).

The aim of this study is to define the structure of types of weather on two synoptic stations: Galle (WMO No 43495, 06 $02^{\circ} \mathrm{N}$, $80^{\circ} 13^{\prime} \mathrm{E}, 9 \mathrm{~m}$ a.s.1.) and Nuwara Eliya (WMO No $43473,06^{\circ} 58^{\prime} \mathrm{N}, 80^{\circ} 46^{\prime} \mathrm{E}, 1880 \mathrm{~m}$ a.s.l.). Both are situated on the Ceylon (Sri Lanka), the Indian Ocean, in the southern part of the Indian subcontinent (Fig. 1). Galle is a lowland station, situated in the south-western part of the 
island, within the coastal belt, where altitudes reach up to $30 \mathrm{~m}$ above sea level. Nuwara Eliya is a station lying on highlands, where the average height of terrain amounts about $1500 \mathrm{~m}$ above sea level (Pathirana 1980). The differences in the topography of both stations entail that they have a different type of climate, although they are being spaced apart only about $118 \mathrm{~km}$ from each other. According to the Köppen climate classification, Galle represents a tropical rainforest climate (Af), while Nuwara Eliya marine - mild winter $(\mathrm{Cfb})$ (Martyn 2000). The average annual maximum air temperature is in Galle $28.9^{\circ} \mathrm{C}$, and in Nuwara Eliya $20.1^{\circ} \mathrm{C}$, while the average annual minimum air temperature is for Galle $24.2^{\circ} \mathrm{C}$ and for Nuwara Eliya $10.7^{\circ} \mathrm{C}$. At both stations, the warmest month of the year is May, and the coldest January (Takahashi and Arakawa 1981). In terms of annual rainfall, both stations are located in the wet zone, but in two variations: Galle in the maritime wet zone and Nuwara Eliya in hill country wet zone. The climate of both stations is dominated by the mentioned topographical features of the region and the South-West monsoon regional scale wind regimes. The season of South-West Monsoon lasts from May to August, bringing rain to the South- and West-coast regions (Galle), as well as central highlands (Nuwara Eliya). The dry season in these regions is from December to March. There is also an intermonsoonal period in October and November when rain and thunderstorms can occur in many parts of the island. This is due to extensive system of cyclones over the Bay of Bengal (Niggol Seo et al. 2005). The mean annual rainfall is estimated to be $2510 \mathrm{~mm}$ in Galle and $2160 \mathrm{~mm}$ in Nuwara Eliya (Takahashi and Arakawa 1981). Due to location of the two stations in the equatorial zone, there is a clear differentiation in the course of the annual individual meteorological elements. Therefore, this paper constitutes a comparison of the basic elements of the structure of weather in mountainous and lowland areas in the equatorial zone. It may seem that the climate of Sri Lanka is quite well described in literature. Existing works, however, are a part of a general climatology. There are no works in the literature treating climate of Sri Lanka as a complex of weather conditions. This work is characteristic of the climate using complexes of weather (weather types), which are several co-occurring meteorological elements at the same time. For this region, it is a new approach. The complement of the research is the analysis of the interannual variability of types, classes and groups of the weather. The knowledge of changes in the frequency and type of weather is used in social and economic life of man. Almost every area of human life, eg. agriculture and energy, is adjusted to the changing climatic conditions and their consequences.

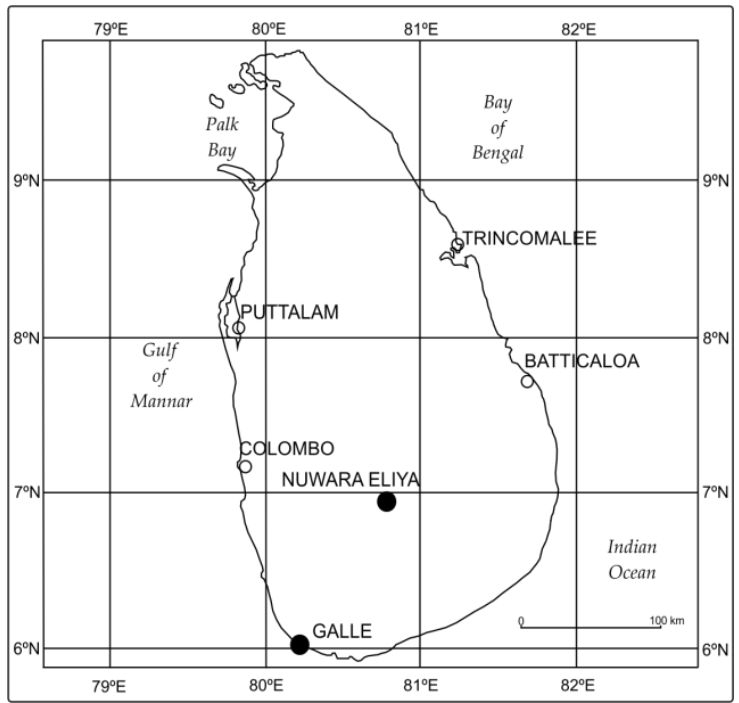

Fig.1. Location of the meteorological stations in Sri Lanka used in this article

\section{Data and method}

Data to characterize the structure of types of weather are the average daily air temperature, the average daily total cloud amount and the daily precipitation amount. The data were obtained from the meteorological database OGIMET (Valor and López 2014) and come for the period April 2002 - March 2014. 
In order to determine the types of weather used method of the classification of weather types based on the A. Woś (2010) typology. The unit of grouping data in this classification is the day.

Meteorological elements which were taken into account were:

- thermal state of the air (T) determined by the average daily temperature (Tavg) and the course of the air temperature during the day (Tmax, Tmin);

- cloudiness $(\mathrm{N})$ determined by the mean diurnal cloudiness;

- precipitation (R) (occurence or lack of precipitation during a day).

To determine the thermal conditions designated 10 intervals of air temperature values. The reason for such a high variation of ranges of air temperature, which may seem unnecessary to characterize the climate of Sri Lanka, is, this paper is a part of a larger research on the typology of the weather types in different climatic zones of Asia. Moreover, the range of values of these intervals has been changed compared to A. Woś's (2010) classification. This is due to A. Woś (2010) typology was created for midlatitude. The cloudiness of the sky is characterized by 3 intervals, and precipitation by 2 . The ranges of these intervals remained the same as in the A. Woś classification. As a result of a combination of selected meteorological elements and gradations of their values, designated 60 types of weather (tab.1). Each type of weather is marked with three digit code - TNR. The first digit refers to the temperature range, the second to the cloudiness, and the third to precipitation. For example, the type of weather written as 921 represents very warm weather, partly cloudy, without precipitation. The basic unit in this classification is the weather type, which defines all days having a uniform description of all three meteorological elements, and therefore, identical digital code (TNR). In addition, at this typology also stands out:

- a group of weather - the unit grouping all days with similar conditions of thermals;

- a subgroup of weather - additional unit characterized by days with the same thermal conditions and cloudiness;

- a class of weather - units aggregating in it all days uniformly in relation to their cloudiness and precipitation.

Tab.1. Weather classification after A. Woś, little modified.

\begin{tabular}{|c|c|c|c|}
\hline Weather element & Symbol & Names of weathers & Partition \\
\hline \multirow{10}{*}{$\begin{array}{c}\text { Air } \\
\text { temperature } \\
\text { (T) }\end{array}$} & 0 & exceptionally warm & $\mathrm{T}_{\text {avg }} \geq 30.0^{\circ} \mathrm{C}, \mathrm{T}_{\min }>0^{\circ} \mathrm{C}$ \\
\hline & 9 & very warm & $20.0^{\circ} \mathrm{C} \leq \mathrm{T}_{\mathrm{avg}}<30.0^{\circ} \mathrm{C}, \mathrm{T}_{\min }>0^{\circ} \mathrm{C}$ \\
\hline & 8 & warm & $10.0^{\circ} \mathrm{C} \leq \mathrm{T}_{\mathrm{avg}}<20.0^{\circ} \mathrm{C}, \mathrm{T}_{\min }>0^{\circ} \mathrm{C}$ \\
\hline & 7 & moderately warm & $0 \leq \mathrm{T}_{\mathrm{avg}}<10.0^{\circ} \mathrm{C}, \mathrm{T}_{\min }>0^{\circ} \mathrm{C}$ \\
\hline & 6 & transitional (frosty - thawly) & $\mathrm{T}_{\min } \leq 0^{\circ} \mathrm{C}, \mathrm{T}_{\max }>0^{\circ} \mathrm{C}$ \\
\hline & 5 & moderately frosty & $-10.0^{\circ} \mathrm{C}<\mathrm{T}_{\mathrm{avg}} \leq 0^{\circ} \mathrm{C}, \mathrm{T}_{\max }<0^{\circ} \mathrm{C}$ \\
\hline & 4 & frosty & $-20.0^{\circ} \mathrm{C}<\mathrm{T}_{\mathrm{avg}} \leq-10.0^{\circ} \mathrm{C}, \mathrm{T}_{\max }<0^{\circ} \mathrm{C}$ \\
\hline & 3 & very frosty & $-30.0^{\circ} \mathrm{C}<\mathrm{T}_{\mathrm{avg}} \leq-20.0^{\circ} \mathrm{C}, \mathrm{T}_{\max }<0^{\circ} \mathrm{C}$ \\
\hline & 2 & execeptionaly frosty & $-40.0^{\circ} \mathrm{C}<\mathrm{T}_{\mathrm{avg}} \leq-30.0^{\circ} \mathrm{C}, \mathrm{T}_{\max }<0^{\circ} \mathrm{C}$ \\
\hline & 1 & extremely frosty & $\mathrm{T}_{\mathrm{avg}} \leq-40.0^{\circ} \mathrm{C}, \mathrm{T}_{\max }<0^{\circ} \mathrm{C}$ \\
\hline \multirow{3}{*}{$\begin{array}{l}\text { Cloudiness } \\
\text { (N) }\end{array}$} & 1 & blue sky & $\mathrm{N} \leq 20 \%$ \\
\hline & 2 & partly cloudy & $\mathrm{N}$ od 20 do $79 \%$ \\
\hline & 3 & cloudy & $\mathrm{N} \geq 80 \%$ \\
\hline \multirow[t]{2}{*}{ Precipitation $(\mathrm{R})$} & 0 & no precipitation & $\mathrm{R}_{\mathrm{d}}<0.1 \mathrm{~mm}$ \\
\hline & 1 & precipitation & $\mathrm{R}_{\mathrm{d}} \geq 0.1 \mathrm{~mm}$ \\
\hline
\end{tabular}


Classified in the weather types days were grouped and specified the average annual, decadal and monthly frequency of particular classification units and frequency of sequences with the same types of weather. Decade means in this study a ten-day period. Each month of the year has been divided into 3 decades, the first decade includes the first 10 days of the month, the second from the 11th to the 20th day of the month, and the third from 21 st to 28 , 30 or 31 , depending on the length of the month). Moreover, for each station the core of the structure of weather types were determined. As in the previous work of the author (Dobrowolska 2013) the core of the structure of weather types is constituted by most frequently observed weather types, of which the cumulative frequency of occurrence is over $70 \%$.

\section{The structure of weather types}

\section{Frequency of occurrence of weather groups} and subgroups

A weather group includes all days that are homogeneous in terms of air temperature, and subgroups - of air temperature plus cloudiness. Table 2 and 3 presents the frequency of occurrence of groups and subgroups of the weather. At both stations, the weather conditions were very stable. In researched period at Galle and Nuwara Eliya were recorded 2 groups of weather, but one of them occurred very rarely.

In Galle $99.75 \%$ of the observations were days with very warm weather (9NR), when the average daily temperature was in the range of $20.0^{\circ}-30.0^{\circ} \mathrm{C}$, and only 11 days in the 12 analyzed years, with exceptionally warm weather $(0 \mathrm{NR})$, with average daily temperature above $30.0^{\circ} \mathrm{C}$. This small thermal diversity during the year is a result from geographical location of Galle station near the Equator, in tropical rainforest climates.
In Nuwara Eliya the dominating weather type was warm weather (8NR), with an average daily temperature in the range of $10.0^{\circ}-20.0^{\circ} \mathrm{C}(99.98 \%)$. Very warm weather (9NR) observed once in the analyzed period $(0.02 \%)$. Nuwara Eliya is also located near the Equator, but at much higher altitude, hence lower, however, aligned values of air temperature, during a year.

At both stations frequency of weather subgroups were very similar to each other. The dominant subgroup, regardless of the air temperature, was partly cloudy weather. At Galle represents $76.01 \%$ of the observations, and in Nuwara Eliya 57.06\%. The cloudy weather at Galle was marked by a frequency of $20.65 \%$, and $36.0 \%$ in Nuwara Eliya. Least days per year were recorded with the blue sky weather (Galle - 3.29\%, Nuwara Eliya 6.94\%). Figure 2 and 3 presents the frequency of occurrence of weather subgroups at selected meteorological stations in Ceylon in particular months of the year. The analysis shows that at both Galle and Nuwara Eliya were listed several subgroups of weather occurring in all months of the statistical year. In Galle it was mainly very warm, partly cloudy weather (92R - 75.82\%) and very warm, cloudy weather (93R - 20.63\%). The very warm, blue sky weather (91R - 3.28\%) observed although in all months of the year, but during the period of April-November shows a marginal percentages. Other weather subgroups appeared only a few times in the analyzed period. In Nuwara Eliya observed 4 weather subgroups, including one - very warm, partly cloudy weather (92R), which was recorded only once in the researched period of 12 years. In all the months of the year a high frequency of occurrence characterized weather: warm, partly cloudy $(82 \mathrm{R}-57.04 \%)$ and warm, cloudy (83R - 36.00\%). Warm, blue sky weather $(81 \mathrm{R}-6.94 \%)$ was also observed during the whole year and was characterized by a higher frequency in the months JanuaryMarch. 
Tab.2. Frequency of occurrence [\%] of groups and subgroups of weather at Galle in the period of April 2002March 2014.

\begin{tabular}{|c|c|c|c|c|c|c|}
\hline \multirow[t]{2}{*}{ No } & \multirow[t]{2}{*}{ Groups } & \multirow[t]{2}{*}{ Subgroups } & \multicolumn{2}{|c|}{ Weather groups } & \multicolumn{2}{|c|}{ Weather subgroups } \\
\hline & & & Frequency & $\begin{array}{l}\text { Cumulative } \\
\text { frequency }\end{array}$ & Frequency & $\begin{array}{l}\text { Cumulative } \\
\text { frequency }\end{array}$ \\
\hline \multirow[t]{3}{*}{1} & \multirow[t]{3}{*}{ 9NR } & 91R & \multirow[t]{3}{*}{99.75} & \multirow[t]{3}{*}{99.75} & 3.29 & 3.29 \\
\hline & & 92R & & & 75.82 & 79.11 \\
\hline & & 93R & & & 20.63 & 99.75 \\
\hline \multirow[t]{3}{*}{2} & \multirow[t]{3}{*}{ ONR } & $01 \mathrm{R}$ & \multirow[t]{3}{*}{0.25} & \multirow[t]{3}{*}{100.00} & 0.02 & 99.77 \\
\hline & & 02R & & & 0.21 & 99.98 \\
\hline & & 03R & & & 0.02 & 100.00 \\
\hline
\end{tabular}

Tab.3. Frequency of occurrence [\%] of groups and subgroups of weather at Nuwara Eliya in the period of April 2002- March 2014

\begin{tabular}{|c|c|c|c|c|c|c|}
\hline \multirow[t]{2}{*}{ No } & \multirow[t]{2}{*}{ Groups } & \multirow[t]{2}{*}{ Subgroups } & \multicolumn{2}{|c|}{ Weather groups } & \multicolumn{2}{|c|}{ Weather subgroups } \\
\hline & & & Frequency & $\begin{array}{l}\text { Cumulative } \\
\text { frequency }\end{array}$ & Frequency & $\begin{array}{l}\text { Cumulative } \\
\text { frequency }\end{array}$ \\
\hline \multirow[t]{3}{*}{1} & \multirow[t]{3}{*}{$8 \mathrm{NR}$} & $81 \mathrm{R}$ & \multirow[t]{3}{*}{99.98} & \multirow[t]{3}{*}{99.98} & 6.94 & 6.94 \\
\hline & & $82 \mathrm{R}$ & & & 57.04 & 63.98 \\
\hline & & $83 \mathrm{R}$ & & & 36.00 & 99.98 \\
\hline \multirow[t]{3}{*}{2} & \multirow[t]{3}{*}{ 9NR } & $91 \mathrm{R}$ & \multirow[t]{3}{*}{0.02} & \multirow[t]{3}{*}{100.00} & 0.00 & 99.98 \\
\hline & & $92 \mathrm{R}$ & & & 0.02 & 100.00 \\
\hline & & $93 \mathrm{R}$ & & & 0.00 & 100.00 \\
\hline
\end{tabular}

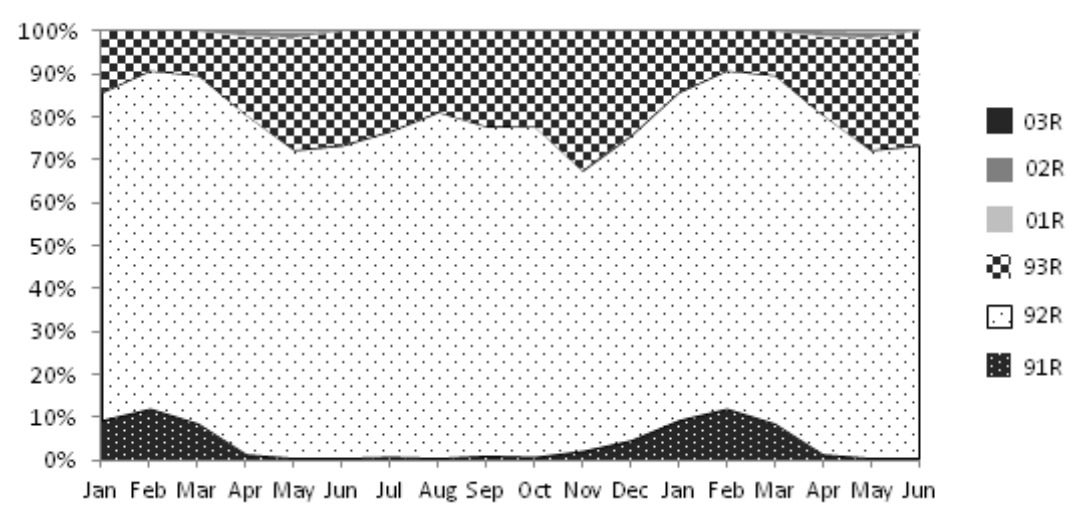

Fig.2. Annual structure of subgroups of weather in Galle (April 2002- March 2014)

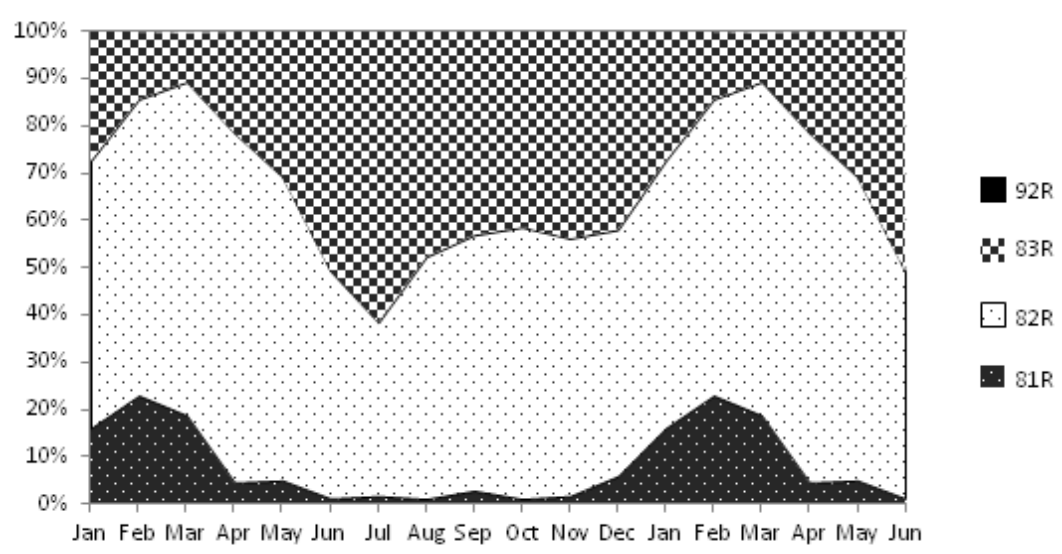

Fig.3. Annual structure of subgroups of weather in Nuwara Eliya (April 2002- March 2014) 
Overall measure of the variability of the weather may be the number of occurring groups of weather recorded in a given unit of time (month, decade). The greater number of weather units demonstrates the greater variability of weather conditions from year to year. The number of groups of weather occurring in consecutive decades in the year at selected stations was specific because of the climate prevailing in them. On average, at both stations, there was only one group of weather. Once in the study period in Nuwara Eliya were recorded two groups. This occurred in the 7th decade of the year. In Galle the period when two weather groups were recorded were the decades 10-11 and 13-14 (first two decades of April and May). In that period in Galle, highest temperatures are recorded annually which is related to the height of the sun above the horizon, which reaches the highest value of the year (Fig. 4).

The frequency of occurrence of weather classes

The weather class aggregates features of different amount of cloudiness and precipitation. At both stations observed all 6 of the possible to occur with that classification of weather classes. The incidence of the different classes of weather varies at selected stations (tab. 4). In Galle and Nuwara Eliya the most frequent was partly cloudy weather without precipitation (T20). In Galle it slightly exceeded $40 \%$ in frequency, while in Nuwara Eliya $30 \%$. At Galle weather partly cloudy with precipitation (T21) was observed next with $35.22 \%$ frequency. These two mentioned classes were recorded at Galle for almost 273 days in an average year (76\%). At Nuwara Eliya first two classes - weather marked as T20 (partly cloudy without precipitation) and $\mathrm{T} 31$ (cloudy with precipitation) had very similar to each frequency - about $30 \%$. In total, were listed on 233 days a year $(64.03 \%)$. Third place in the ranking of the frequency of weather classes took in Galle cloudy with precipitation weather (T31 - 16.49\%), while in Nuwara Eliya partly cloudy with precipitation weather (T21 - 24.41\%). The other 3 weather classes (T30 - cloudy weather with no precipitation, T10 - blue sky weather with no precipitation and T11 - blue sky weather with precipitation) have not reached frequency above $7 \%$.

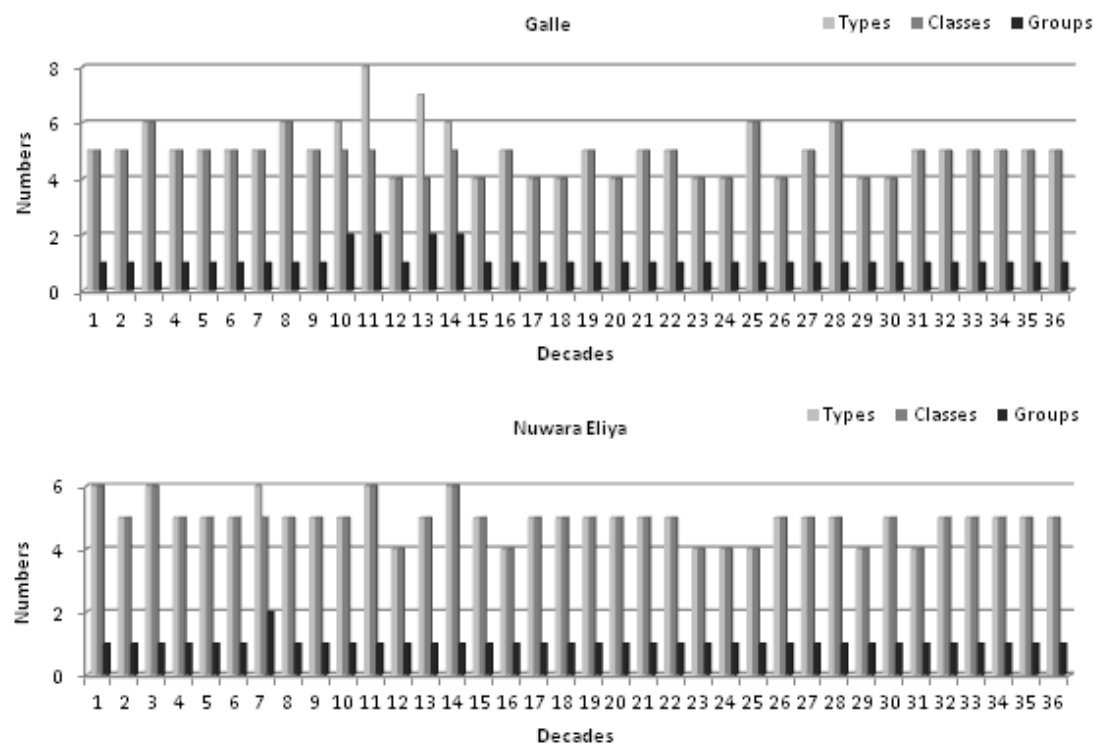

Fig.4. Number of groups, classes and weather types recorded at selected stations in consecutive decades of the year (April 2002- March 2014) 


\section{The frequency of occurrence of weather types}

A weather type includes all days that are homogenous in terms of thermal conditions, cloudiness and precipitation. Weather conditions at Ceylon stations show a high monotony and slight variation in the annual course of meteorological elements. During the analyzed period 10 at Galle and 7 types at Nuwara Eliya were observed. The predominant type of weather at plain station Galle was very warm, partly cloudy weather with no precipitation $(920-41.10 \%)$, and at Nuwara Eliya, slightly colder, warm, partly cloudy weather with no precipitation (820 - 32.63\%). In second place at Galle was very warm, partly cloudy weather with precipitation (921 $34.66 \%$ ), while in Nuwara Eliya warm, cloudy weather with precipitation (831 - 31.37\%). Next, at Galle was very warm, cloudy weather with precipitation $(931-16.28 \%)$, and at Nuwara Eliya warm, partly cloudy weather with precipitation $(821-24.41 \%)$. Types of weather at both stations in the fourth and fifth place characterized similar frequencies (Galle 4.40\% and 3.21\%; Nuwara Eliya - $6.77 \%$ and $4.63 \%$ ). These were the types: 930 - very warm, cloudy weather with no precipitation and 910 - very warm, blue sky weather with no precipitation (Galle), 810 - warm, blue sky weather with no precipitation and 830 - warm, cloudy weather with no precipitation (Nuwara Eliya).

The remaining five types listed in Galle and 2 in Nuwara Eliya characterized the turnout of less than $1 \%$. In the analyzed period were recorded less than 7 times and had a marginal importance in the annual structure of types of weather. At both stations a mere few types constitute the core of structure of the weather types ( $70 \%$ of the observations). In the case of Galle, 2 types are characterised by a total of more than $70 \%$ of the frequency, while in Nuwara Eliya 3 (tab. 5).
Weather variability from year to year at selected stations was low as evidenced by the distribution of the number of types of weather in different decades of the year. Distribution of the number of types of weather in particular decades of the year for both stations is as nearly equal to the distribution of number of weather classes. This is due to the presence of an average of one weather group a year at the studied stations. Average number of types in the decade at both stations was 5. This means that in average decade, certain types of weather occur annually. The occurrence of the number of types of weather in the decade less than 10 indicates that the average duration of one or more types of weather is greater than 1 day. Only in the decade of 11 (second decade of April) and 13 (the first decade of May) were observed more types in Galle - respectively 8 and 7 (Fig. 4). The analyzed variability of the number of groups, classes and types of weather in the years 2003-2013 for both stations is slightly different. For any station cannot determine trends in the structure of types of weather. Derogations from the most frequently listed number of individual classification units appear to be random in nature. In Nuwara Eliya in 2003, 2004, 2009 and 2013 recorded more than usual about one type of weather. In Galle the greatest number of weather types was observed in 2010 - 8 and 2013 - 7 (Fig. 5).

Figures 6 and 7 illustrates changes in frequency of the most frequently recorded 5 types of weather in the following years of the period 2003-2013. Their analysis shows that the weather type marked 921 (very warm, partly cloudy weather with precipitation) in Galle was characterized by decreasing frequency of occurrence, while frequency of type designated as 920 (very warm, partly cloudy weather without precipitation) and 931 (very warm, cloudy weather with precipitation) has increased. 
Tab.4. Frequency of occurrence [\%] of weather classes at Galle and Nuwara Eliya in the period April 2002March 2014

\begin{tabular}{|c|c|c|c|c|c|c|c|}
\hline \multicolumn{4}{|c|}{ Galle } & \multicolumn{4}{c|}{ Nuwara Eliya } \\
\hline No & $\begin{array}{c}\text { Class } \\
\text { of weather }\end{array}$ & Frequency & $\begin{array}{c}\text { Cumulative } \\
\text { frequency }\end{array}$ & No & $\begin{array}{c}\text { Class of } \\
\text { weather }\end{array}$ & Frequency & $\begin{array}{c}\text { Cumulative } \\
\text { frequency }\end{array}$ \\
\hline 1 & T20 & 40.78 & 40.78 & 1 & T20 & 32.66 & 32.66 \\
\hline 2 & T21 & 35.22 & 76.00 & 2 & T31 & 31.37 & 64.03 \\
\hline 3 & T31 & 16.49 & 92.50 & 3 & T21 & 24.41 & 88.44 \\
\hline 4 & T30 & 4.39 & 96.88 & 4 & T10 & 6.77 & 95.22 \\
\hline 5 & T10 & 3.03 & 99.91 & 5 & T30 & 4.63 & 99.84 \\
\hline 6 & T11 & 0.10 & 100.00 & 6 & T11 & 0.16 & 100.00 \\
\hline
\end{tabular}

Tab.5. Frequency of occurrence [\%] of weather types at Galle and Nuwara Eliya in the period April 2002March 2014

\begin{tabular}{|c|c|c|c|c|c|c|c|}
\hline \multicolumn{4}{|c|}{ Galle } & \multicolumn{4}{c|}{ Nuwara Eliya } \\
\hline No & $\begin{array}{c}\text { Types } \\
\text { of weather }\end{array}$ & Frequency & $\begin{array}{c}\text { Cumulative } \\
\text { frequency }\end{array}$ & No & $\begin{array}{c}\text { Types } \\
\text { of weather }\end{array}$ & Frequency & $\begin{array}{c}\text { Cumulative } \\
\text { frequency }\end{array}$ \\
\hline 1 & 920 & 41.10 & 41.10 & 1 & 820 & 32.63 & 32.63 \\
\hline 2 & 921 & 34.66 & 75.76 & 2 & 831 & 31.37 & 64.00 \\
\hline 3 & 931 & 16.28 & 92.04 & 3 & 821 & 24.41 & 88.41 \\
\hline 4 & 930 & 4.40 & 96.44 & 4 & 810 & 6.77 & 95.19 \\
\hline 5 & 910 & 3.21 & 99.65 & 5 & 830 & 4.63 & 99.81 \\
\hline 6 & 021 & 0.12 & 99.76 & 6 & 811 & 0.16 & 99.97 \\
\hline 7 & 911 & 0.09 & 99.86 & 7 & 920 & 0.02 & 100.00 \\
\hline 8 & 020 & 0.09 & 99.95 & - & - & - & - \\
\hline 9 & 010 & 0.02 & 99.97 & - & - & - & - \\
\hline 10 & 030 & 0.02 & 100.00 & - & - & - & - \\
\hline
\end{tabular}
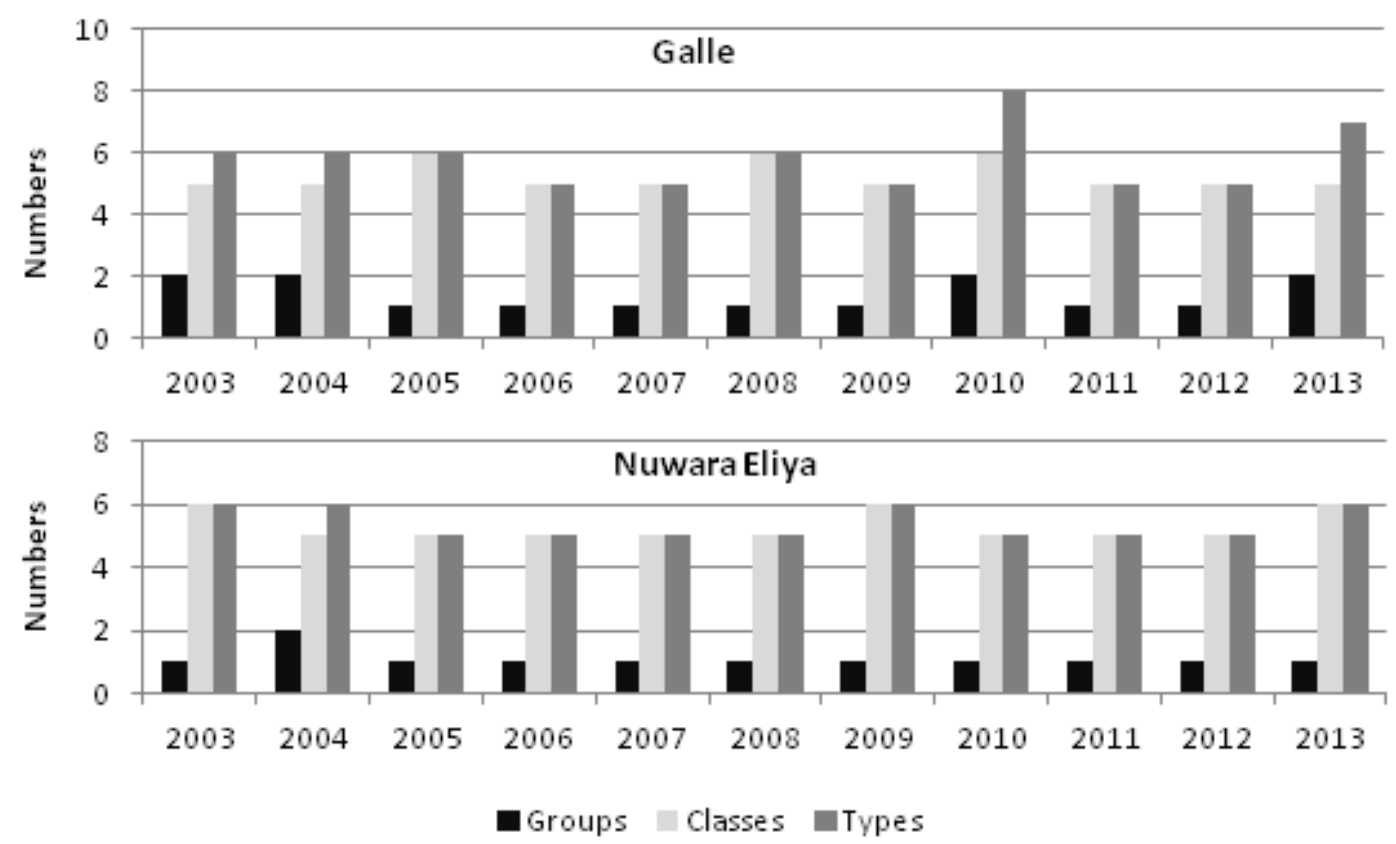

Fig.5. Number of groups, classes and weather types recorded at selected stations in years 2003-2013 


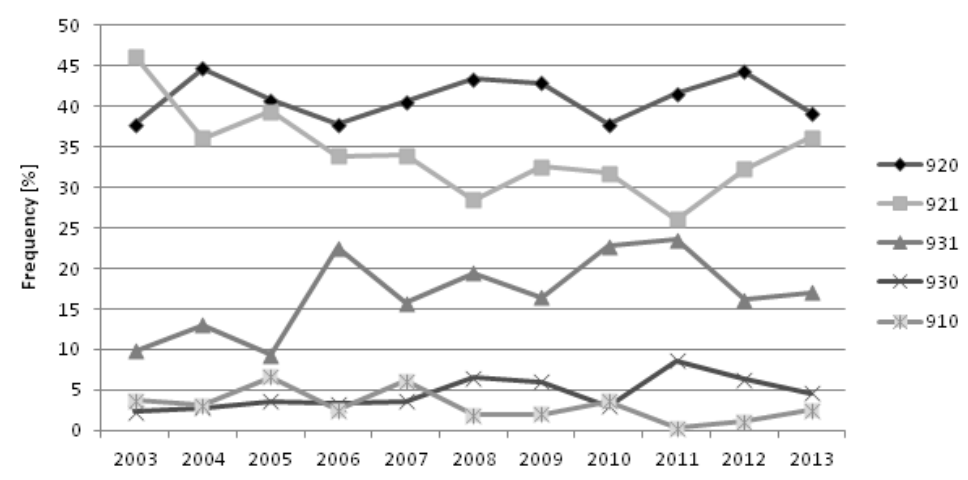

Fig.6. Changes in the frequency of occurrence of selected types of weather in Galle (2003-2013)

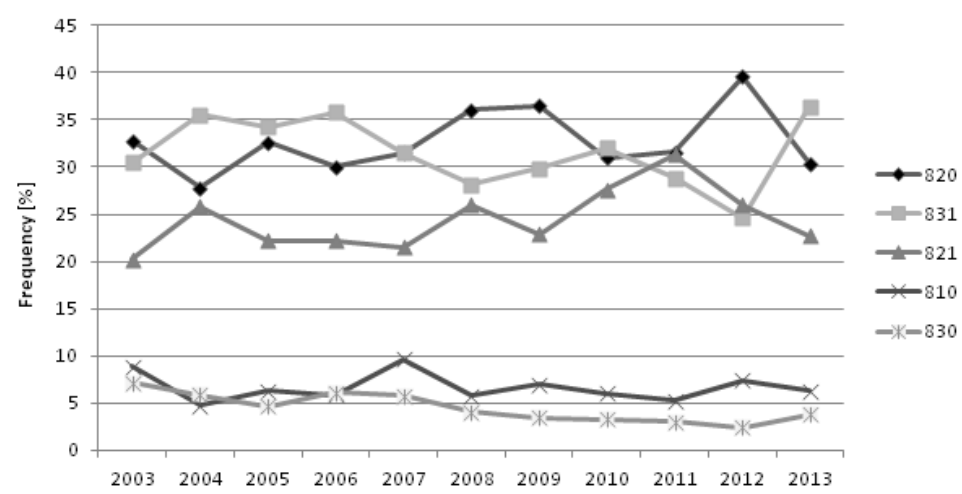

Fig.7. Changes in the frequency of occurrence of selected types of weather in Nuwara Eliya (2003-2013)

However, in Nuwara Eliya the growth of frequency in the coming years was observed for type 821 (warm, partly clouded weather with precipitation) and 820 (warm, partly clouded weather, without precipitation). The frequency of rare types of weather (930 and 910 for Galle; and 810 i 830 for Nuwara Eliya) had a similar value in all the researched years.

\section{The length and occurrence of dominant weather types sequences}

A sequence of days with the same type of weather informs which types of weather increase the stability of the weather conditions. For a sequence with the weather type it is considered occurrence of two consecutive days with the same type of weather. The unit of length within the particular type of the weather is the day. The conducted calculations show that more sequences with the same type of weather were observed in Galle (893) than in Nuwara Eliya (869). However, the difference between the stations is small. Frequency distribution of sequences of days with weather types is very similar to each other at both stations. In the entire study period were observed sequences days in length from 2 to 20 days. However, the longer the sequence with the same weather type was, the less frequently was it observed. For example, at both stations the longest sequences: nineteen-day, twentyday were observed just once. In Galle they appeared to weather marked code 920, which is the most common, and in Nuwara Eliya with the weather 831. Almost half of the listed sequences represent the shortest - a two-day (Galle - 49.03\% and Nuwara Eliya - 45.71\%). More than one fifth were the sequences of a three-day ones. Sequences of four had 
frequency nearly $10 \%$. The incidence of other sequences was less than $7 \%$. Most sequences were observed with the most common types of weather. At Galle the most frequent were sequences with very warm, partly cloudy weather without precipitation (920 - 41.39\%), while at Nuwara Eliya warm, partly cloudy weather without precipitation (820 - 36.48\%).

\section{Conclusions}

The paper presents the comparison of structure of weather types at Ceylon meteorological stations located in equatorial zone, however, at different heights above sea level - lowland Galle and highland Nuwara Eliya in period April 2002- March 2014. A feature of climatic conditions of the two stations is small variation in weather conditions, which is reflected in the small number of weather types listed during a statistical year. A small number of them contributes to the fact that the recorded types of weather achieve a large frequency, which in turn means that the type of weather lasts very long. The most frequent weather type in Galle
- very warm, partly cloudy weather without precipitation (920) maintains an average of more than 150 days during a year, and in Nuwara Eliya - warm, partly cloudy weather without precipitation (820) - 119 days a year. A small variation in weather conditions is reflected also in the range of the types of weather. In Galle occurred primarily very warm weather types, while in Nuwara Eliya types of warm weather. In addition, for both stations observed a small number of types that were recorded sporadically in the research period. Analysis of the frequency of occurrence of weather classes allows to conclude, that for the weather changeability in this region, is primarily responsible criterion of cloudiness. The frequency of distribution of weather classes at both stations was quite different. In the year at both stations clearly dominant were days of partly cloudy with no precipitation weather (T20). In Galle has represented approximately 40\% (146 days of the year), and in Nuwara Eliya 33\% (120 days of the year). During the year, at both stations, slightly prevailed days with precipitation.

Tab.6. The length and occurrence of dominant weather types sequences at Galle in the period April 2002- March 2014

\begin{tabular}{|c|c|c|c|c|c|c|c|}
\hline \multirow{2}{*}{$\begin{array}{l}\text { The number of days } \\
\text { within sequence }\end{array}$} & \multicolumn{6}{|c|}{ Type of weather } & \multirow[t]{2}{*}{ Sum } \\
\hline & 920 & 921 & 931 & 910 & 930 & 021 & \\
\hline 2 & 17.10 & 20.75 & 7.41 & 2.17 & 1.60 & 0.00 & 49.03 \\
\hline 3 & 7.98 & 8.67 & 3.76 & 0.57 & 0.34 & 0.11 & 21.44 \\
\hline 4 & 5.93 & 3.76 & 1.94 & 0.23 & 0.00 & 0.00 & 11.86 \\
\hline 5 & 3.65 & 1.82 & 1.37 & 0.00 & 0.00 & 0.00 & 6.84 \\
\hline 6 & 2.17 & 0.68 & 0.46 & 0.00 & 0.00 & 0.00 & 3.31 \\
\hline 7 & 1.71 & 0.91 & 0.11 & 0.11 & 0.00 & 0.00 & 2.85 \\
\hline 8 & 0.91 & 0.57 & 0.23 & 0.00 & 0.00 & 0.00 & 1.71 \\
\hline 9 & 0.46 & 0.23 & 0.00 & 0.00 & 0.00 & 0.00 & 0.68 \\
\hline 10 & 0.46 & 0.23 & 0.23 & 0.00 & 0.00 & 0.00 & 0.91 \\
\hline 11 & 0.57 & 0.11 & 0.00 & 0.00 & 0.00 & 0.00 & 0.68 \\
\hline 12 & 0.11 & 0.00 & 0.00 & 0.00 & 0.00 & 0.00 & 0.11 \\
\hline 13 & 0.11 & 0.11 & 0.00 & 0.00 & 0.00 & 0.00 & 0.23 \\
\hline 14 & 0.00 & 0.11 & 0.00 & 0.00 & 0.00 & 0.00 & 0.11 \\
\hline 19 & 0.11 & 0.00 & 0.00 & 0.00 & 0.00 & 0.00 & 0.11 \\
\hline 20 & 0.11 & 0.00 & 0.00 & 0.00 & 0.00 & 0.00 & 0.11 \\
\hline Sum & 41.39 & 37.97 & 15.51 & 3.08 & 1.94 & 0.11 & 100.00 \\
\hline Total & 41.39 & 79.36 & 94.87 & 97.95 & 99.88 & 100.00 & \\
\hline
\end{tabular}


Tab.7. The length and occurrence of dominant weather types sequences at Nuwara Eliya in the period April 2002- March 2014

\begin{tabular}{|c|c|c|c|c|c|c|c|}
\hline \multirow{2}{*}{$\begin{array}{l}\text { The number of days } \\
\text { within sequence }\end{array}$} & \multicolumn{6}{|c|}{ Type of weather } & \multirow[t]{2}{*}{ Sum } \\
\hline & 820 & 831 & 821 & 810 & 830 & 811 & \\
\hline 2 & 15.99 & 12.34 & 12.88 & 3.00 & 1.39 & 0.11 & 45.71 \\
\hline 3 & 7.51 & 5.79 & 5.47 & 1.72 & 0.54 & 0.00 & 21.03 \\
\hline 4 & 4.94 & 2.90 & 3.65 & 0.86 & 0.00 & 0.00 & 12.34 \\
\hline 5 & 3.22 & 2.47 & 0.75 & 0.43 & 0.00 & 0.00 & 6.87 \\
\hline 6 & 2.58 & 2.25 & 0.86 & 0.11 & 0.00 & 0.00 & 5.79 \\
\hline 7 & 0.86 & 1.29 & 0.00 & 0.21 & 0.00 & 0.00 & 2.36 \\
\hline 8 & 0.54 & 0.86 & 0.11 & 0.21 & 0.00 & 0.00 & 1.72 \\
\hline 9 & 0.21 & 0.43 & 0.21 & 0.00 & 0.00 & 0.00 & 0.86 \\
\hline 10 & 0.21 & 0.97 & 0.00 & 0.00 & 0.00 & 0.00 & 1.18 \\
\hline 11 & 0.11 & 0.21 & 0.11 & 0.11 & 0.00 & 0.00 & 0.54 \\
\hline 12 & 0.11 & 0.32 & 0.00 & 0.00 & 0.00 & 0.00 & 0.43 \\
\hline 13 & 0.11 & 0.43 & 0.00 & 0.00 & 0.00 & 0.00 & 0.54 \\
\hline 14 & 0.00 & 0.11 & 0.00 & 0.00 & 0.00 & 0.00 & 0.11 \\
\hline 15 & 0.11 & 0.21 & 0.00 & 0.00 & 0.00 & 0.00 & 0.32 \\
\hline 19 & 0.00 & 0.11 & 0.00 & 0.00 & 0.00 & 0.00 & 0.11 \\
\hline 20 & 0.00 & 0.11 & 0.00 & 0.00 & 0.00 & 0.00 & 0.11 \\
\hline Sum & 36.48 & 30.79 & 24.03 & 6.65 & 1.93 & 0.11 & 100.00 \\
\hline Total & 36.48 & 67.27 & 91.31 & 92.27 & 99.89 & 100.00 & \\
\hline
\end{tabular}

More of them observed at the highlands station Nuwara Eliya than lowland Galle. Similarly to the study of Manawadu and Fernando (2008) has observed the slight decrease in the number of days with precipitation in Galle, and a slight increase in the Nuwara Eliya. Despite the significant difference in topography of both stations, the described structures of weather types are quite similar to each other. Nuwara Eliya, as a mountain station, was characterized by lower average diurnal temperatures, a higher percentage of days with high cloud cover over $79 \%$, and a higher percentage of days with precipitation in a year than Galle. Both are characterized by significant weather monotony, which genesis should be related to the location in the vicinity of the Equator.

\section{References}

Czubukow Ł.A. (1949) Kompleksnaja klimatołogia. Izdatielstwo Akademii Nauk SSSR, Moskwa-Leningrad, 1-84.

Dobrowolska K. (2013) Typy pogody na Wyspie Kotelnyj (Wyspy
Nowosyberyjskie). Problemy Klimatologii Polarnej, 23, 77-92.

Ferdynus J. (1999) Główne cechy klimatu morskiego strefy subpolarnej północnego Atlantyku w świetle struktury stanów pogód. Wyższa Szkoła Morska, Gdynia.

Ferdynus J., Marsz A. A. (2000) Struktura stanów pogody i sezonowość pogodowa [in:] Marsz A.A., Styszyńska A. (eds.). Główne cechy klimatu rejonu Polskiej Stacji Antarktycznej im. H. Arctowskiego, Wyd. Akademii Morskiej w Gdyni, Gdynia, 143-162.

Ferdynus J. (2004) Roczna struktura stanów pogody w Hornsundzie (SW Spitsbergen). Polish Polar Studies, XXX International Polar Symposium, Gdynia, 81-94.

Ferdynus J. (2007) Struktura stanów pogody i sezonowość pogodowa [in:] Marsz A A. i Styszyńska A. (eds.). Klimat rejonu Polskiej Stacji Polarnej w Hornsundzie. Wyd. Akademii Morskiej w Gdyni, Gdynia, 205-234.

Ferdynus J. (2013) States of the weather and weather seasonality [in:] Marsz A. A. Styszyńska A. (eds.). Climate and Climate 
Change at Hornsund, Svalbard, Gdynia Maritime University, Gdynia, 221-251.

Howe G.F (1925) The summer and winter weather of selected cities in North America. Monthly Weather Review, 10, 427-429.

Kossowski J. (1968) O częstości głównych typów pogody w Polsce, Przegląd Geofizyczny, 13 (21), 3, 283-292.

Maheras P. (1984) Weather-type classification by factor analysis in the Thessaloniki area, Journal of Climatology, 4 (4), 437-443.

Manawadu L., Fernando N. (2008) Climate Changes in Sri Lanka. University of Colombo Review, Journal of the University of Colombo, Sri Lanka, New Series; Vol:1, 02.

Marsz A.A. (1992) Struktura pogód i roczna sezonowość klimatu Stacji Arctowskiego. Problemy Klimatologii Polarnej, 2, 30-49.

Martyn D. (2000) Klimaty kuli ziemskiej. Wyd. Naukowe PWN, Warszawa.

Michailidou C., Maheras P., ArseniPapadimititriou A., Kolyva-Machera F., Anagnostopoulou C., (2009) Study of weather types at Athens and Thessaloniki and their relationship to circulation types for the cold-wet period, part I: Two-step cluster analysis. Theoretical and Applied Climatology, 97, 1-2, 163-177.
Nichols E.S. (1925) A classification of weather types. Monthly Weather Review, 10, 431434.

Niggol Seo S., Mendelsohn R., Munasinghe M. (2005) Climate change and agriculture in Sri Lanka: a Ricardian valuation. Environment and Development Economics 10: 581-596.

Pathirana, H.D.N.C. (1980) Geology of Sri Lanka in relation to Plate Tectonics. L. Natn. Sci. Coun. Sri Lanka v. 8, 75-85.

Piotrowicz K. (2010) Sezonowa i wieloletnia zmienność typów pogody w Krakowie. Instytut Geografii i Gospodarki Przestrzennej Uniwersytetu Jagiellońskiego, Kraków.

Takahashi K., Arakawa Y. (eds) (1981) Climates of Southern and Western Asia. World Survey of Climatology Volume 8. Elsevier Scientific publishing Company, Amsterdam-Oxford-New York, 67-182.

Woś A. (1996) Struktura sezonowa klimatu Polski. Bogucki Wydawnictwo Naukowe, Poznań.

Woś A. (2010) Klimat Polski w drugiej połowie XX wieku. Wydawnictwo Naukowe UAM, Poznań.

Valor G.B., López D.J.M.G. (2014) OGIMET - professional information about meteorological conditions in the world, Internet adress: http://www.ogimet.com/; (last access: July 2013). 